\title{
Pelatihan Etika Bisnis dan Pembukuan Sederhana Pelaku UMKM di Kelurahan Klampis Ngasem Surabaya
}

\author{
*Mega Arisia Dewi \\ Sekolah Tinggi Ilmu Ekonomi Indonesia (STIESIA) Surabaya \\ "E-mail : megaarisiadewi@stiesia.ac.id \\ DOI: https://doi.org/10.21107/pangabdhi.v6i2.7476 \\ Naskah diterima 20 Juli 2020, Revisi 27 Juli 2020, Terbit 29 Oktober 2020
}

\begin{abstract}
Abstrak
Usaha Mikro Kecil Menengah (UMKM) di Kota Surabaya memiliki banyak potensi usaha yang menjadi sumber mata pencarian utama penduduk di sekitarnya, mulai dari industri makanan, industri kerajinan, industri tekstil, dan industri agrobisnis yang semuanya dapat berkembang pesat. Kelurahan Klampis Ngasem adalah salah satu kelurahan yang memiliki UMKM yang memiliki prospek yang cukup bagus di kota Surabaya. Pada era persaingan global saat ini, UMKM di Kota Surabaya dituntut agar mampu bersaing dengan UMKM dari daerah lain. UMKM Klampis Ngasem dibekali ilmu dan pelatihan yang bermanfaat bagi keberlangsungan UMKM mereka, salah satunya melalui Pelatihan Etika Bisnis dan Pembukuan Sederhana bagi pelaku UMKM. Pelatihan ini sangat diperlukan dalam upaya mengembangkan bisnis mereka dalam menghadapi persaingan bisnis di era globalisasi saat ini. Melalui pelatihan ini diharapkan dapat memberikan manfaat tambahan bagi para pelaku UMKM khususnya di UMKM Kelurahan Klampis Ngasem Surabaya
\end{abstract}

Kata Kunci : etika bisnis, pembukuan sederhana, UMKM

\begin{abstract}
Micro Small and Medium Enterprises (MSMEs) in the city of Surabaya have have a great business potential which is the main source of livelihood for the surrounding population, ranging from the food industry, handicraft, textile and agribusiness, all of which can develop rapidly. Klampis Ngasem Urban Village is one of the Sub-District MSMEs that have good prospects in the city of Surabaya. In the current era of global competition, MSMEs in Surabaya City are demanded to be able to compete with other regions. The Klampis Ngasem MSMEs are needed to be equipped with knowledge and training that is useful for the sustainability of their MSMEs, one of them is through Business Ethics Training and Simple Bookkeeping for MSME practitioners. Training on Business Ethics and Simple Bookkeeping is very much needed in an effort to develop their business in facing business competition in the current era of globalization. It is hoped that Business Ethics Training and Simple Bookkeeping can provide additional benefits for MSME principals, especially in MSMEs, Klampis Ngasem Sub-District, Surabaya.
\end{abstract}

Key Words : business ethics; simple book-keeping; MSMEs

\section{PENDAHULUAN}

Zimmerer dan Scarborough (2004) menjelaskan bahwa kewirausahaan merupakan salah satu faktor pendorong dalam meningkatkan perekonomian melalui proses penerapan inovasi dan kreativitas agar kehidupan bisnis bisa diperbaiki dan berjalan lancar. Kewirausahaan diharapkan mampu menyediakan lapangan pekerjaan dan meningkatkan kesejahteraan diri sendiri dan masyarakat salah satunya melalui Usaha Mikro Kecil Menengah (UMKM) (Kurniawan, 2020).

Budiarto et.al (2018) mengungkapkan bahwa selain koperasi, UMKM merupakan pilar perekonomian nasional. Berdasarkan Peraturan
Perundang-undangan No. 20 tahun 2008, UMKM adalah usaha produktif yang dimiliki perorangan maupun badan usaha yang telah memenuhi kriteria sebagai usaha mikro.

Sesuai dengan pengertian UMKM tersebut maka kriteria UMKM dibedakan secara masingmasing meliputi usaha mikro, usaha kecil, dan usaha menengah. Selain itu, UMKM dapat diartikan sebagai pengembangan kawasan andalan untuk mempercepat pemulihan perekonomian untuk mewadahi program prioritas dan pengembangan berbagai sektor dan potensi. Sedangkan usaha kecil merupakan peningkatan berbagai upaya pemberdayaan masyarakat.

Melalui UMKM ini, diharapkan dapat 
meningkatkan kreatifitas dan kemampuan masyarakat dalam menyalurkan ide dan kreasinya dengan memanfaatkan sumber daya alam yang tersedia. UMKM memiliki peran strategis pada perekonomian Indonesia yang dilihat dari kedudukannya diantaranya : (1) sebagai pemain utama dalam kegiatan ekonomi di berbagai sektor; (2) penyedia lapangan kerja yang terbesar; (3) pemain penting dalam pengembangan kegiatan ekonomi lokal pemberdayaan masyarakat; (4) pencipta pasar baru dan sumber inovasi, serta ; (5) menjaga neraca pembayaran melalui kegiatan ekspor.

Kota Surabaya memiliki banyak potensi usaha yang menjadi sumber mata pencarian utama penduduk di sekitarnya, mulai dari industri makanan, industri kerajinan, industri tekstil, dan industri agrobisnis yang semuanya dapat berkembang pesat. Pembangunan ekonomi di Kota Surabaya 98 persen ditopang dari sektor pedagang ekonomi kecil mikro (UMKM), sisanya 2 persen dari perusahaan besar. Hal ini mampu terwujud karena selama ini para pelaku UMKM diajarkan ilmu untuk bersaing melalui Go Global Go Digital (Topan, 2019).

Kini, produk mereka sudah setara dengan produk yang ada di luar negeri, ungkap Walikota Surabaya. Selain itu, ada pembelajaran go financial yang mengajarkan pelaku UKM mencari bentuk-bentuk modal agar para pelaku usaha industri kreatif mampu meningkatkan kapasitasnya untuk lebih luas mencari jaringan melalui teknologi. Sekarang Batik Surabaya, fashion, handycraft dan lain-lain sudah diekspor ke luar negeri seperti Afrika dan Eropa. Pelaku UMKM diharapkan lebih berdaya baik bagi dirinya sendiri maupun bagi Kota Surabaya serta mampu menyerap ilmu kemudian disumbangkan kepada warga yang lain agar lebih sejahtera (Effendi, 2018).

Menurut Prasetyo (2008), masalah yang dihadapi UMKM adalah banyak tantangan yang harus dihadapi oleh pelaku usaha agar dapat bersaing di pasar global. Masalah tersebut adalah masalah internal maupun eksternal diantaranya masalah modal, teknik produksi, pangsa pasar, manajemen, dan teknologi, serta lemah dalam pengambilan keputusan, pengawasan keuangan, rendahnya daya saing, persoalan perijinan, bahan baku, lokasi pemasaran, sulitnya memperoleh kredit bank, iklim usaha yang kurang kondusif, kepedulian masyarakat, dan kurang pembinaan. Selain itu, UMKM juga diharapkan dapat meningkatkan daya saing kapasitas dan kapabilitasnya. Selain permodalan, masih banyak kendala yang dihadapi UMKM seperti belum memiliki pasar yang tetap dan berkelanjutan, terutama bagi pasar ekspor. Pemerintah sudah mengeluarkan kebijakan ekonomi untuk mendorong pertumbuhan UMKM diantaranya, pemberian fasilitas promosi, produk sehat, sertifikasi produk halal hingga Standar Nasional Indonesia (SNI). Termasuk kebijakan suku bunga yang ringan bagi permodalan usaha rakyat. Untuk mendapatkan permodalan, UMKM harus memenuhi persyaratan diantaranya, nasabah calon kreditur harus memiliki kegiatan usaha yang menghasilkan, memiliki cashflowkemampuan untuk membayar, terbuka kepada bank.

Selain itu, masalah yang dihadapi UMKM adalah tentang masalah Etika Bisnis. Etika bisnis merupakan hal yang penting dalam bidang usaha baik untuk perusahaan maupun lingkungannya karena berkat etika bisnis sektor usaha kecil dan menengah atau UMKM bisa bertahan dan tetap eksis biarpun hanya dalam sektor kecil. Dalam menentukan barang apa yang dijual dan dibutuhkan konsumen serta strategi dalam berjualan/pemasaran semua itu ada dan termasuk dalam etika bisnis.

Menurut Fahmi (2013), prinsip etika bisnis perlu diperhatikan oleh para penjual karna didalamnya memuat 5 hal yang bisa membuat bisnis kita berjalan dengan baik. Kelima prinsip tersebut adalah: (1) Prinsip otonomi (kemampuan untuk mengambil keputusan); (2) Prinsip keadilan (menuntut setiap orang agar diperlakukan adil dan objektif); (3) Prinsip saling menguntungkan (menuntut semua pihak dapat saling menguntungkan); (4) Prinsip integritas moral (menuntut agar para pebisnis dapat menjaga nama baik perusahaan) dan (5) Prinsip kejujuran (berlaku jujur kepada semua pihak). Apabila kelima prinsip tersebut dapat diaplikasikan dengan baik, maka akan membawa keuntungan bagi UMKM, sesuai dengan tujuan utama yaitu memperoleh laba/keuntungan dan usaha yang dijalankan pun dapat bertahan lama berkat kelima prinsip tersebut.

\section{METODE}

Kegiatan pengabdian masyarakat ini dilakukan dalam rentang waktu bulan Desember 2019 hingga Januari 2020. Peserta yang berpartisipasi adalah para pelaku UMKM Kelurahan Klampis Ngasem Kota Surabaya. Kegiatan ini tidak hanya melibatkan para pelaku UMKM dan Akademisi saja, tetapi juga turut melibatkan peran aktif dari Perguruan Tinggi 
yaitu STIESIA, Camat Sukolilo dan Lurah Klampis Ngasem yang turut serta membantu hingga terselenggaranya kegiatan abdimas ini dengan baik dan lancar.

Metode yang digunakan dalam pelatihan ini dibagi menjadi 3 (tiga) tahapan yaitu (1) pelatihan tentang materi etika bisnis; (2) pelatihan tentang pembukuan keuangan sederhana; dan (3) program pendampingan mengenai aktivitas wirausaha dan pembukuan keuangan sederhana. Dimana masing-masing tahap diberikan materi yang terkait dan dilakukan pendampingan secara bertahap untuk mengaplikasikan materi yang diperoleh. Tujuan dilakukan pendampingan adalah agar para pelaku UMKM Kelurahan Klampis Ngasem terbiasa menghadapi segala kondisi dan persitiwa yang terjadi selama proses mengembangkan bisnis mereka.

\section{HASIL DAN PEMBAHASAN}

Pengabdian kepada masyarakat adalah suatu kegiatan yang bertujuan membantu masyarakat tertentu dalam beberapa aktivitas khususnya dalam mengembangkan kesejahteraan dan kemajuan masyarakat Indonesia. Kegiatan Pelatihan dilakukan dalam 3 (tiga) tahapan yaitu tahap pelatihan mengenai etika bisnis, pelatihan mengenai pembukuan sederhana dan pendampingan untuk mengaplikasikan materi yang diperoleh.

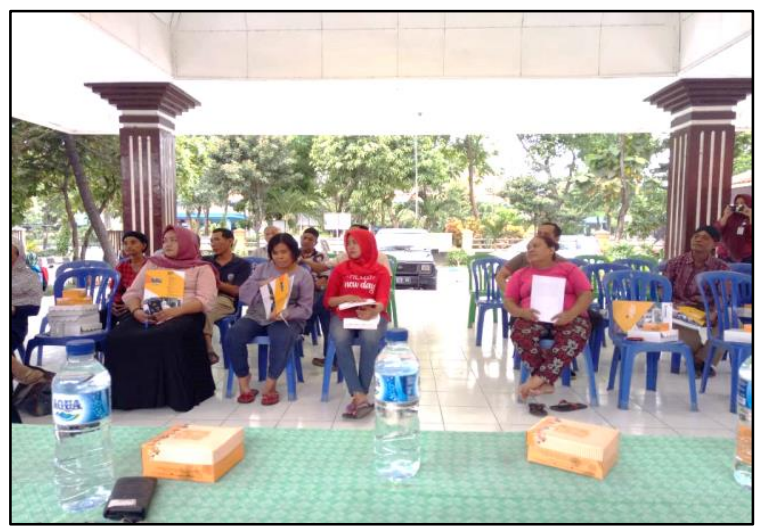

Gambar 1. Kehadiran Peserta Pelatihan

Jumlah peserta yang hadir sebanyak 20 orang. Para peserta yang hadir diminta mengisi terlebih dahulu daftar hadir yang telah disediakan, kemudian kami membagikan masing-masing fotokopi materi yang akan diberikan kepada pelaku usaha UMKM. Selama pemaparan materi, peserta nampak antusias dengan langsung mengajukan pertanyaan, dan terdapat beberapa peserta pula yang berminat untuk belajar lebih lanjut mengenai cara menghitung harga pokok penjualan untuk menentukan harga jual yang bisa memberikan laba bagi mereka.

Pada pelatihan Etika Bisnis, para pelaku UMKM diberikan materi dalam memahami etika dalam dunia bisnis. Dimana dalam materi ini diberikan gambaran mengapa etika bisnis diperlukan dalam kegiatan bisnis yang mana notabene dalam proses bisnis sekarang sering terjadi kecurangan yang dilakukan oleh para pelaku bisnis tanpa memperhatikan dampak baik maupun buruk untuk pelaku bisnis lainnya. Padahal dalam etika bisnis lebih mengutamakan pertimbangan moral daripada pertimbangan hukum serta harus bijak dalam menggunakan pertimbangan moral dalam melakukan suatu perbuatan. Sedangkan pada pelatihan Pembukuan Sederhana, para pelaku diberikan materi bagaimana menghitung harga pokok penjualan, harga pokok produksi, harga jual dan perhitungan dalam menentukan laba untuk hasil produksi mereka.

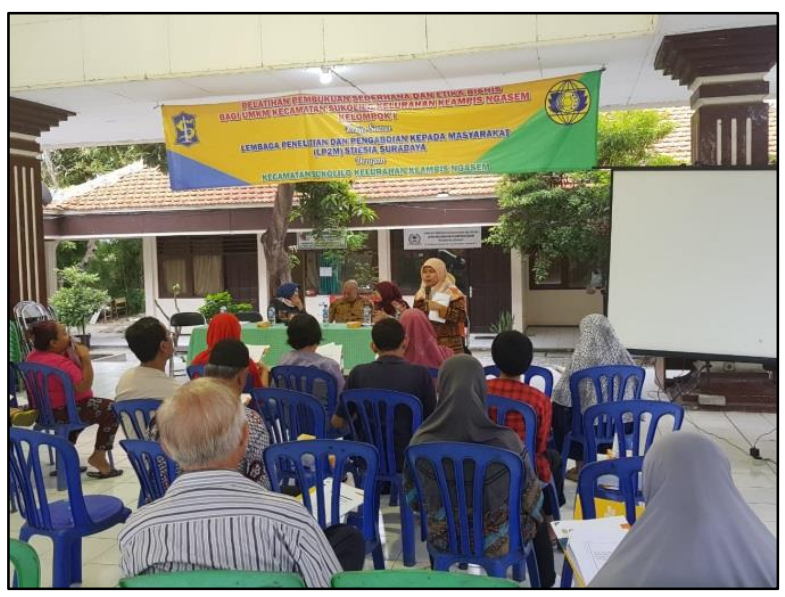

Gambar 2. Penyampaian Materi

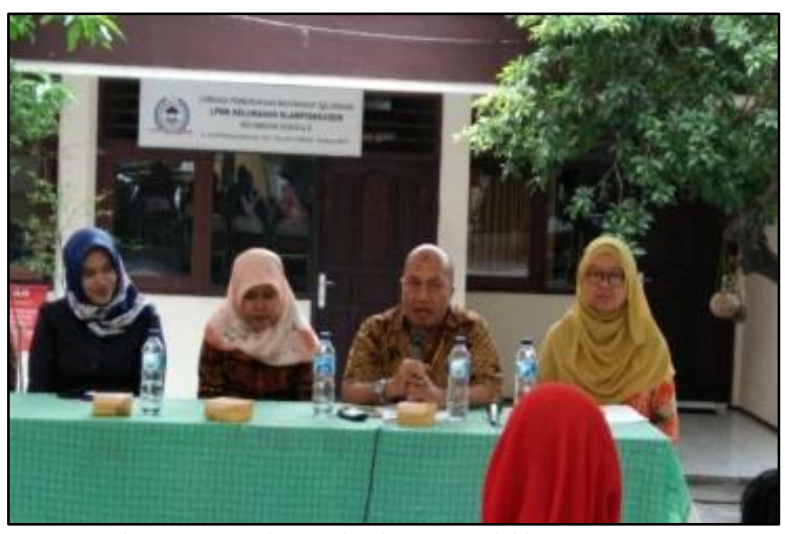

Gambar 3 Arahan dari perwakilan Perguruan

Tinggi dan Lurah Klampis Ngasem

Setelah pemaparan materi selesai, kegiatan selanjutnya adalah melakukan pendampingan kepada para pelaku UMKM. Pendampingan dilakukan dengan maksud agar pelaku UMKM mampu mengaplikasikan materi yang telah diperoleh pada tahapan sebelumnya. Pada 
tahapan ini, para pelaku UMKM mulai melakukan identifikasi kekuatan, kelemahan, peluang dan ancaman dalam proses pengembangan bisnis.

Setelah melakukan identifikasi, dilanjutkan dengan kegiatan memetakan beberapa kekuatan dan peluang yang dapat menghasilkan dampak lebih bagi mereka dan menganalisis kelemahan yang dimiliki dan ancaman yang akan terjadi pada bisnis mereka. Hasil dari kegiatan pelatihan ini diharapkan para pelaku UMKM mampu menemukan solusi yang tepat dalam mengembangkan serta memperluas usaha mereka dan dapat meningkatkan produktivitas UMKM dan diharapkan mampu membuka lapangan pekerjaan di Kota Surabaya.

\section{KESIMPULAN}

Kegiatan pengabdian kepada masyarakat yang diterapkan melalui pelatihan materi etika dan prinsip bisnis ini dapat memberi manfaat kepada khalayak luas serta perlu adanya kesinambungan kegiatan dan evaluasi setelah kegiatan pengabdian kepada masyarakat ini dilakukan, sehingga para pelaku UMKM di Surabaya dapat berkontribusi dalam pengembangan UMKM di Indonesia.

\section{DAFTAR PUSTAKA}

Budiarto, R., Putero, S. H., Suyatna, H., Astuti, P., Saptoadi, H., Ridwan, M. M., \& Susilo, B. 2018. Pengembangan UMKM Antara Konseptual dan Pengalaman Praktis.

\section{UGM PRESS.}

Effendi, Z. 2018. https://news.detik.com/beritajawa-timur/d-3904062/wali-kota-rismaingin-ukm-surabaya-lebih-kompetitif

Fahmi, I. 2013. Etika Bisnis. Alfabeta. Bandung.

Kementerian Koperasi dan UKM. 2005. Peran Usaha Mikro, Kecil dan Menengah Dalam Pembangunan Ekonomi Nasional. Surabaya.

Kurniawan, K. 2019. Tujuh Pengertian Kewirausahaan Menurut Para Ahli. (online) https://projasaweb.com/pengertiankewirausahaan/

Prasetyo, P.E. 2008. Peran Usaha Mikro Kecil dan Menengah (UMKM) dalam Kebijakan Penanggulangan Kemiskinan dan Pengangguran. Akmenika UPY, 2(1), p113.

Topan, M. A. 2019. Mekari Bidik Pelaku UMKM Surabaya.

(on-line) https://www.wartaekonomi.co.id/read2577 62/mekari-bidik-pelaku-ukm-surabayalewat-software-khusus

Undang-Undang Republik Indonesia. 2008. Undang-Undang Nomor 20 Tentang Usaha Mikro, Kecil dan Menengah. Jakarta.

Zimmerer, T. W \& Scarborough, N. M. 2004. Pengantar Kewirausahaan dan Manajemen Bisnis Kecil. Edisi Bahasa Indonesia. PT Indeks. Jakarta. 